\title{
原著
}

\section{上顎中切歯・歯冠色調の分布 ${ }^{*}$}

\author{
Study on the Distribution of Color \\ in Upper Central Incisors*
}

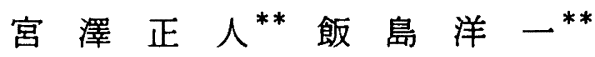 \\ Masato MIYAZAWA ${ }^{* *}$ and Youichi IIJIMA** \\ Received August 3, 1987; accepted August 11, 1987
}

\begin{abstract}
The aim of this study was to evaluate the distribution of tooth color by using the color difference (CIE1976L*a*b*) between standard material (white board) and subjects. We analyzed the color of sound upper central incisors by using a colorimeter (BM-5, TOKYO OPTICAL CO., LTD JAPAN).

Eighty-one young adults (aged 22-30 years, 81 teeth) and 103 children (aged 7-15 years, 103 teeth) were examined (Total 184 subjects).

Sixteen cases of discolored teeth and 30 cases of enamel opacity (white spot, dental fluorosis) were included.

The results were as follows.

1. The distribution of color differences in the total cases of normal teeth color groups in adults and children showed a normal distribution curve in goodness of fit tests of normality $(p<0.05)$.

2. The mean of color differences in all subjects was 23.9 in enamel opacity, 34.9 in normal teeth, and 48.9 in discolored teeth. Differences among all means were statistically significant $(p<0.05)$ according to the Newman-Keuls test. A similar statistical significance was obtained in children $(p<0.05)$, and in adults significant differences were found between discolored teeth and normal teeth, discolored teeth and enamel opacity.
\end{abstract}

3. When comparing the mean of color differences of the normal tooth distribution to either the distribution of the typical discolored tooth or typical enamel opacity, the standard deviation made it possible to compare the distance between the 3 groups.

The results of this study suggest the possibility of screening in differentiating tooth color using this method.

索引用語：菌冠色調，色差，分布，色彩計，野外研究

Koy words: Tooth color, Color difference, Distribution, Colorimeter, Field study

\footnotetext{
**本論文の一部は第33回日本口腔衛生学会総会において発表した

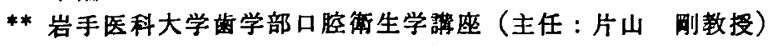

** Department of Preventive Dentistry, Iwate Medical University School of Dentistry (Director: Prof. Tsuyoshi KATAYAMA) 特別揭载
} 


\section{緒言}

歯冠色調の補緅学・保存学領域の研究では, 色調を䠦 床上重要な審美的要素のひとつとしてとらえていること から，従来，標管色標や shade guide を利用した視感 的測色法 ${ }^{1-4}$ による調查結果が多数報告されてきた。最 近では測色器機を利用して光学的に直接測定した 報 告5-8) も多く認められるようになってきた。光学的な測 色法の特徴は，色調を客観的に評価しようとする点にあ る。

一方，菌冠色譋の異常などの疫学調査では ${ }^{9-177}$ ，測色 器機を利用した報告例は少ない現状にある。著者らも， 色調の異常について，視診を主体とした方法を利用した 調查結果について報告17してきた。色調は視跈によって 評価された場合，診查者の主観に左右されやすく，その 判定法は客観的判定法とは言い難い。そこで本研究は, 歯冠色調の分布を明らかにする目的で，測色器機を利用 して歯冠色調を客観的に測定した。

齿冠色調は，年龄群別（小归ならぴに成人）, 症例別 （正常歯冠色歯群, 着色歯群, 白斑歯群) に検討された。

\section{対象と方法}

\section{1. 測色装置}

Fig. 1 に測色装置の概要を示す。歯冠色調は色彩輝 度計（東京光学, BM-5) を用いて, オプティカルフ アイバー照明器 (Dolan-Jenner システム181 B 光源：タ ングステン八ロゲンランプ 色温度 $3300 \mathrm{~K}$ )による照明下 で測定された。本計器が出力する情報は，XYZ 表色 系 ${ }^{181}$ の三刺激值 $\mathrm{X}, \mathrm{Y}, \mathrm{Z}$ および色度座標 $\mathrm{x}, \mathrm{y}$ である。

本計器の特徴は, 試料と非接触で測定可能な望遠型で あること，ならびに，試料との距離および色彩辉度計本 体の視角を変えることにより，測定面積を任意に設定で きることなと゚である。

\section{2. 測色条件}

予備実験により最適な測色条件を以下のごとく設定し た (Fig. 1)。

1）試料と光源との距離は, $50 \mathrm{~mm}$ に固定。

2）照明ならびに受光は，JIS Z 8722191 の物体色の 測定方法に準じた。すなわち，試料にたいし近似的に水 平方向 $45^{\circ}$ より照明し正面の反射光を受光。

3）歯牙と測色方向（色彩輝度計の受光方向）の角度 は，測方より観察して，切縁と唇面の歯頚部を結ぶ仮想 線に $90^{\circ}$ となるよう設定。

4）外部照明の影響を除くため, 自然光, 室内照明光

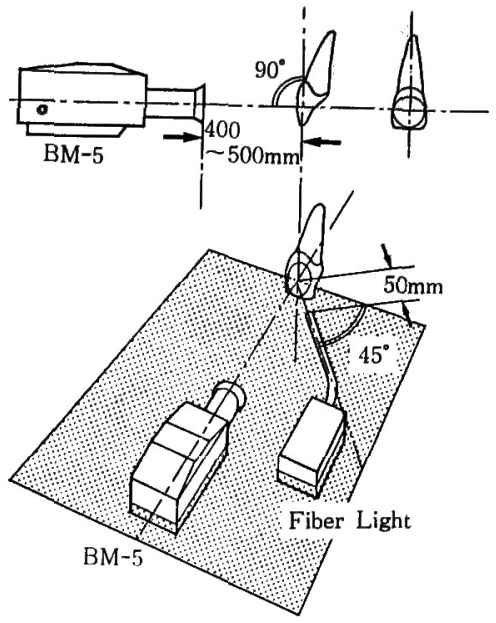

Fig. 1 Schematic illustration of color analyzing system

が測定時に測色システム全体に入射しないよう色彩輝度 計, 光源, 被験者の固定装置全体を被覆した。

1）４）の条件を満たしうるよう色彩耀度計，光源， および被験者の頭部固定器具の全体を一体化した装置を 用いて測定した (Fig. 2)。

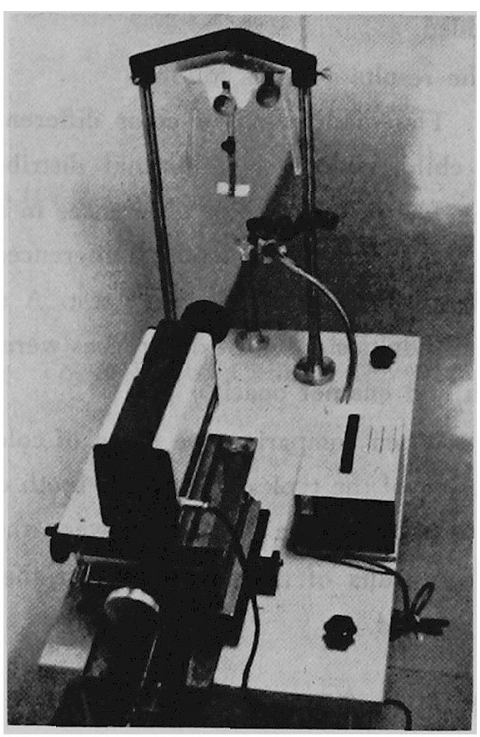

Fig. 2 Photograph of color analyzing system

\section{3. 被験者}

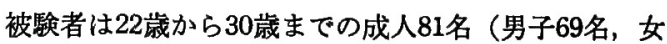
子12名) ならびに小学校, 中学校の児童・生徒103名（7 歳 15歳，男子56名，女子47名）の合計184名である。

測定対象歯は，著しい歯列不正や触触のない左右いず 
れかの健全な上頶中切歯の㻺面であり，歯面乾燥状態で 測定した。

測定部位は, 一歯一部位とし切縁に接し両隣接面隅角 に内接する最大面稓の円とした。本法によれば，唇面全 体に占める被測定面䅡の割合は，55 80\%であった。

\section{4. 曹冠色調の評価}

本研究で用いた色彩輝度計が出力する三刺激值 $(\mathrm{X}$, $\mathrm{Y}, \mathrm{Z})$ および三刺激値をもとに算出される色度座標（x, y）は，複数の数值の組み合わせでなければ色調を評価 できない。

そこで，本研究では色調の分布範囲を検郡するため に，色調を単一の数值で简便に評価可能な指標について 検郡し，評価のための指標として色差 ${ }^{18)}\left(\Delta \mathrm{E}^{*} \mathrm{ab}\right)$ を用 いることとした。すなわち，著者らは比本来の色の見 え方に近似した概念で，色の変化が感賞的に均等な CIELAB 均等色空間 ${ }^{18)}\left(\mathrm{L}^{*} \mathrm{a}^{*} \mathrm{~b}^{*}\right.$ 表色系) に基ずいて, 三刺激值 $(\mathrm{X}, \mathrm{Y}, \mathrm{Z})$ から $\mathrm{L}^{*}, \mathrm{a}^{*}, \mathrm{~b}^{*}$ の三つの指標を算 出した。さらにこれらの複数の指標 $\left(\mathrm{L}^{*}, \mathrm{a}^{*}, \mathrm{~b}^{*}\right)$ を総 合化し，一つの指標として評価可能な標準白色面からの 色差を算出した。

算出式は次の通りである。 $\Delta \mathrm{E}^{*} \mathrm{ab}=\left[\left(\Delta \mathrm{L}^{*}\right)^{2}+\left(\Delta \mathrm{a}^{*}\right)^{2}+\left(\Delta \mathrm{b}^{*}\right)^{2}\right]^{1 / 2}$

\section{結 果}

\section{1. 年舲群別の增冠色調の分布}

Table 1 亿全対象歯の色差の測定結果を小児, 成人 別ならびに症例別に示した。

全対象歯の度数分布は, Fig. 3 に示してある。

全対象歯の場合, 色差は30.0の階級に度数が集中する 傾向を示し，平均值34.3 (S.D. 8.6) を軸として左右対 称性の正規分布に近似した形を示した (Fig. 3)。その 分布型は, 正規分布一の適合度検定の結果, 正規分布と 見なしうることが確認された（P<0.05）。さらに，小 児 (平均値32.8，S.D. 8.4) ならびに成人 (平均値36.2, S.D. 8.4) 別に検討した結果も，全対象歯と同様にいず れも左右対称性の正規分布と見なしうることが確認され た $(\mathrm{P}<0.05)$ 。

また小児と成人の色差の平均值間には統計学的に有意 の差が認められた $(\mathrm{P}<0.05)$ 。

\section{2. 症例別の莑冠色調の分布}

本研究で対象齿とされた 184 例中には，䠦床的に暗褐 色を呈する着色歯（16例）さらにはフッ素症歯やフッ素 以外の原因による白斑，いわゅる White spot (W.S) を有する歯牙 (30例) が認められた。

Table 1 に, 症例別の色差の測定結果を示した。全

Table 1 Results of color difference in adults and children (Upper central incisor).

\begin{tabular}{|c|c|c|c|c|c|}
\hline group & & Discolored & Enamel opacity & Normal & Total \\
\hline $\begin{array}{l}\text { adults } \\
\text { (age }\end{array}$ & Hean \pm S. D. & $\Gamma^{55.9 \pm 10.6}$ & {$\left[\begin{array}{c}29.3 \pm 4.2 \\
\end{array}\right.$} & $35.2 \pm 6.3$ & ए $36.2 \pm 8.4$ \\
\hline \multirow[t]{4}{*}{$22 \sim 30)$} & Max & 76.8 & 34.5 & 48.2 & 76.8 \\
\hline & Min & 47.5 & 25.0 & 20.0 & 20.0 \\
\hline & Range & 29.3 & 9.5 & 28.2 & 56.8 \\
\hline & Nuaber & 5 & 4 & 72 & 81 \\
\hline $\begin{array}{l}\text { Children } \\
\text { (age }\end{array}$ & Hean \pm S. 0 . & $\begin{array}{c}L 45.8 \pm 4.7 \\
L\end{array}$ & $\begin{array}{l}23.1 \pm 4.6 \\
\end{array}$ & $34.5 \pm 5.5$ & $L 32.8 \pm 8.4$ \\
\hline \multirow[t]{4}{*}{ 7〜15) } & Hax & 54.4 & 34.3 & 53.9 & 54.4 \\
\hline & Min & 39.8 & 16.1 & 24.7 & 16.1 \\
\hline & Range & 14.6 & 18.2 & 29.2 & 38.3 \\
\hline & Nuaber & 11 & 26 & 66 & 103 \\
\hline $\begin{array}{r}\text { Total } \\
\text { (age }\end{array}$ & HeantS. D. & $\bigsqcup^{48.9 \pm 8.5}$ & $\stackrel{23.9 \pm 5.0}{\longleftarrow}$ & $\sqrt[34.9 \pm 6.0]{\square}$ & $34.3 \pm 8.6$ \\
\hline \multirow[t]{4}{*}{$7 \sim 30)$} & Max & 76.8 & 34.5 & 53.9 & 76.8 \\
\hline & Min & 39.8 & 16.1 & 20.0 & 16.1 \\
\hline & Range & 37.0 & 18.4 & 33.9 & 60.7 \\
\hline & Nunber & 16 & 30 & 138 & 184 \\
\hline
\end{tabular}

* Significant $(P<0.05)$ 


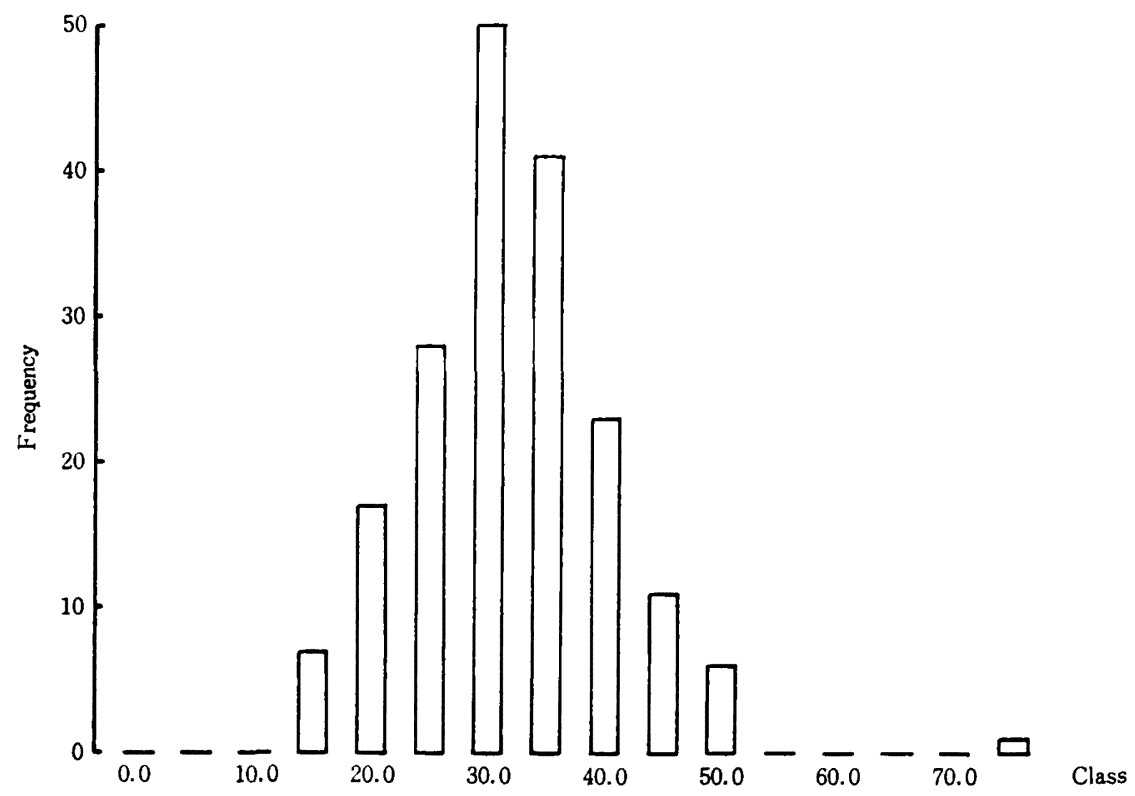

Fig. 3 Distribution of color difference in all subjects

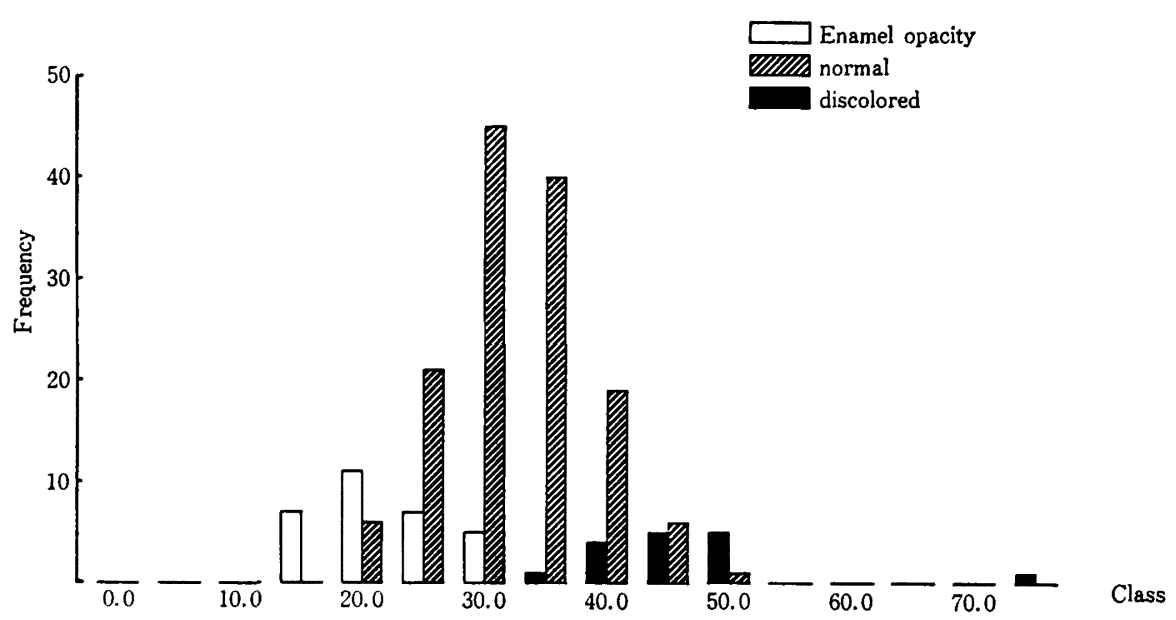

Fig. 4 Distribution of color difference by color condition in all subjects

年龄群では，標準白色面からの色差の平均値は, 着色歯 群が最も高い值を示し，ついで，正常歯冠色歯群，白斑 歯群の順に低い值となることが認められた。とくに白斑 歯群では, その平均值, S.D., Range が共に最小の值 を示した。三群の色差の平均値には, Newman-Keul ${ }^{20)}$ の多重比較の結果, いずれの組み合わせでも統計学的に 有意の差が認められた $(\mathrm{P}<0.05)$ 。

全年龄群の症例別の色差の度数分布を Fig. 4 に示し た。Fig. 4 より明らかなように, 三群の色差の度数分
布はいずれも平均値を中心とする単極性の傾向を示し た。分布の幅は, 着色歯群が最も広く, 次いで正常歯冠 色歯群, 白斑歯群の願であった。正常歯冠色歯群では, 色差30.0，35.0の階級に度数が集中する傾向を示し，そ の平均値 34.9 （S.D. 6.0）を軸として 左右対称性の正 規分布に近似した形を示した。分布型は適合度検定の結 果, 正規分布と見なしうることが確認された $(\mathrm{P}<0.05) 。$ その他の症例では, 統計学的に例数が少ないこともあ り，正規分布であることを確認できなかった。 
着色齿の分布上の特徽は，35.0以上の階級に度数分布 しており, 正常歯冠色齔の分布との重なりが琶められる ものの, 正常歯冠色歯から離れた位置に分布する傾向を 示した。とくに，50.0以上の階級では全症例 7 例中着色 歯が 6 例を占めていた。

白斑齿については，30.0以下の階級に度数分布してお り，着色歯と同様に正常歯冠色齿との重なりが認められ るものの，正常齿冠色齿から離れた位固に分布する傾向 を示し，20.0以下の階級では全症例24例中18例を占めて いた。このことから明らかなように，色調の異常を呈し た症例では，正常歯冠色歯の分布から離れた位圈に分布
する傾向が認められた。また，色差25.0以下の白斑站な らびに45.0以上の着色歯の場合, 正常歯冠色歯の平均值 から約 2 S.D. 離れた位膡に分布していた。

年龄群別, 症例別の色差の測定結果を見ると（Table 1), 正常齿冠色歯群では, 成人（平均值35.2) と小児 （平均值34.5） はほぼ同様の值を示しており，統計学的 にも有意の差を認めなかった。しかしながら，着色齒群 と白斑歯群では, いずれも成人が高い值を示し, 統計学 的にも有意の差が認められた $(\mathrm{P}<0.05)$ 。

症例別の小児の測定結果では, 着色歯群, 正常歯冠色 歯群, 白斑歯群の三群の色差の平均値には, 統計学的検

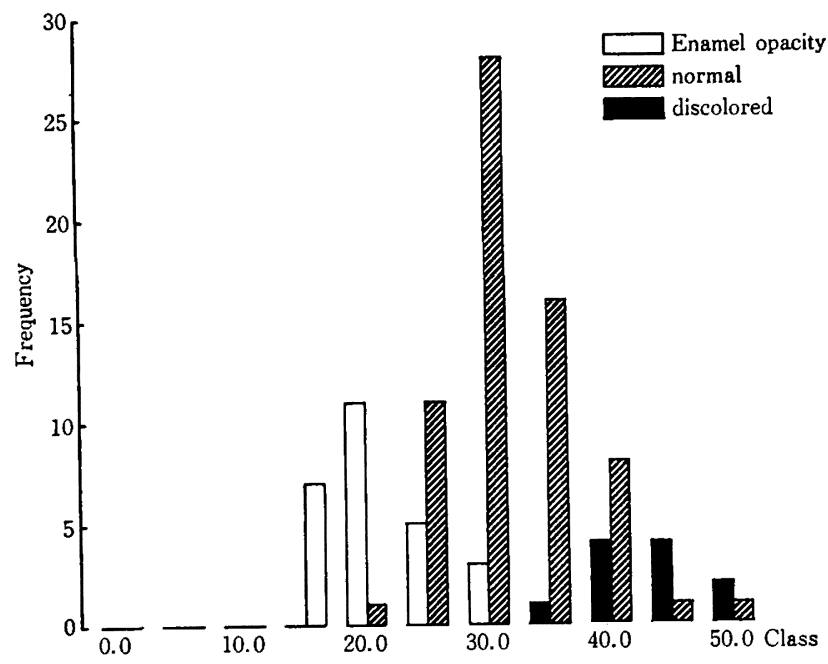

Fig. 5 Distribution of color difference by color condition in children

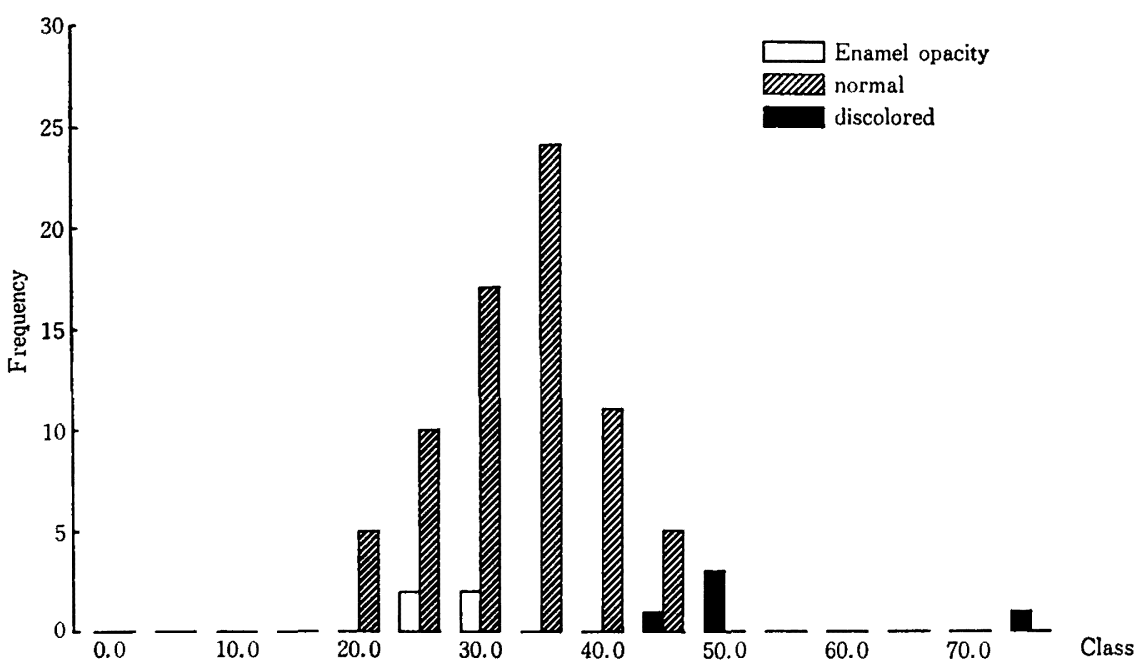

Fig. 6 Distribution of color difference by color condition in adults 
定の結果，いずれの組み合わせでも有意の差が喼められ た $(\mathrm{P}<0.05)$ 。

成人では，着色歯群と白斑歯群，着色歯群と正常歯冠 色歯群の間で統計学的に有意の差が認められた（ $\mathrm{P}<$ 0.05)。

小児と成人の度数分布を，Fig. 5, Fig. 6 に示した。 正常歯冠色歯群の度数分布は，いずれも，30.0，35.0の 階級に度数が集中する傾向を示した。分布型は，適合度 検定の結果，いずれも左右対称性の正規分布と見なしう ることが確認された（P<0.05）。また，明らかな着色 歯や白斑歯は, 正常藏冠色菌群の平均値加約 2 S.D. 離 れた位置に分布する傾向を認めた。

\section{考察}

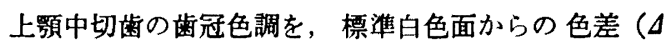
$E^{*} \mathrm{ab}$ ) を指標に客観的に測定し，年龄群別，症例別に 検㶦，評価した。

全症例および正常歯冠色歯群の色差は，小児ならびに 成人ともに，左右対称性の正規分布を示すことが認めら れた。歯冠色調の分布について，丸井2) は，上影前歯部 を対象とした標準歯冠色票を用いた測定結果から，色相， 彩度, 明度の度数分布は正規分布を示すと述へている。 また，平安ら ${ }^{13)}$ も上顥中切歯における Adams の a 值, $\mathrm{b}$ 值の分布は正規分布であること認めており，評価方法 は異なるもののいずれも著者らの成績と一致していた。

年龄群別の全症例の検討で，成人の歯冠色調の色差は 小児に比較して統計学的に有意の差 $(\mathrm{P}<0.05)$ であっ た。この理由は，それぞれに含まれる症例の割合の違 い，とくに白斑苳の寄与によるものと考えられる。すな わち成人の白斑歯群は81例中 4 例であったが，小児では 103 例中26例を占めていたことによる。正常歯冠色歯群 の色差は，興味あることに成人（平均値35.2)，小児 (平 均値34.5) ともに同様の值を示し, 統計学的にも有意の 差は認められなかった。成人と小児の歯冠色調の差異に ついて，宮越ら ${ }^{21}$ ，丸井 ${ }^{21}$ ，中川(5)，上原(1)，は增龄に伴 って明度が低下すると報告している。本研究に用いた指 標が標準白色面からの色差であることを考虛すると，增 齢に伴う明度の低下によって，成人の色差は小児に比較 して高い值を示すと推測された。しかしながら，本研究 においては，両者に明瞭な差を認めることは出来なかっ た。

症例別の分布の特徴は，白斑菌群は正常蒾冠色歯群よ りも狭い匴囲に集中して分布する傾向を示し，着色歯群 では逆に広い範囲に分布していた。しかしながら，白斑
歯や着色歯では，その例数が少ないため分布型を明らか にすることは出来なかった。三群（正常歯冠色歯群, 着 色歯群, 白斑歯群）相互の比較によれば，色差の平均値 は, 着色歯群, 正常歯冠色歯群, 白斑歯群の順で低い值 を示し，統計学的にも有意の差が認められた $(\mathrm{p}<0.05)$ 。 さらに, 着色歯群と白斑歯群の色差の平均值は, 正常歯 冠色歯群の平均值から約 2 S.D. 離九て分布していた。

白斑歯の色差は，小児と成人の間に統計学的に有意の 差が認められた $(\mathrm{P}<0.05)$ 。この要因は, 成人の白斑歯 群の症例の多くは白斑が歯面に局在している症例であっ たことから，白斑以外の被測定歯面の影響を受けたこと が考えられる。加えて，小児の症例の約半数が歯面全体 が白濁を有する歯牙フッ素症の症例であったためと思わ れる。

着色歯の場合も，小児と成人で統計学的に有意の差 （P<0.05）を認めたが，成人の症例のなかに臨床的にも きわめて褐色傾向の強い症例（色差76.8）が含まれてい たことによるものと推定された。ちなみに，この症例を 除いた成人（平均值50.7，S.D. 5.94 例）と小児での 有意差検定の結果，両者に違いを見出すことは出来なか った。

本測色システムを用いて歯冠色調の異常をスクリーニ ング21)できるか否かについて検討した。その結果，白斑 歯では色差 30.0 末満で, 敏感度 0.83 , 特異度 0.82 , 着色 歯では色差 40.0 以上で，敏感度 0.94 , 特異度 0.85 と満足 すべき識別性を示した。すなわち，本測色システムによ れば，白斑歯では色差30.0末満，着色歯では，40.0以上 をスクリーニングレベルとして設定することにより，勃 率的に歯冠色調の異常を識別することが可能であること が示唆された。

橋口22)をはじめ多くの研究者が指摘するように，歯冠 色調は, 重要な審美的要素の一つとして評価される必要 がある。近年の臨床領域の研究では，中川 ${ }^{5}$ が指摘した ように, Shade Guide と人工歯の色調の分布は，天然 歯の分布䈥囲を完全に網罹していないとの反省から，色 彩学的に管理されたカラーチャートの作製など，より客 観性の高い視感的測色法")の開発や，測色器機を利用し た研究 ${ }^{5-8)}$ が認められ，自然感を備えた色調の再現を目 的として，個々の歯の色調を詳細に検討している。すな わち, 色調の隣在歯相互の一致性, 歯種別の差異, 個々 の歯の部位別の検討などの報告が多く認められる。

色調の異常などの疫学調査の例には，評価基準を研究 者自身が設定し，その発言頻度，要因を検討した岡 田昂， Ulvestud ら ${ }^{10)}$ の報告があるが，この方法は診査 
者の主锶に左右されやすい。

一方, 測色器機の応用例には, 小川111, 岩倉 $5^{12}$, 平 安ら ${ }^{13)}$, Kerosuo ら ${ }^{14)}$ の報告が虫められる。小川111 は, 乳齿の着色歯と正常药冠色歯を，明度を指標として度数 分布上で比較検即しているが，正常齿冠色歯の部位別 （歯到部，齿冠中央部，切端部）最頻値の変動は着色齔 に比較して少ないと述へているにすぎない。しかしなが ら, Hunter の表色系において，a 值は着色歯と正常歯 冠色崡では大きく異なると指摘している点は注目され る。

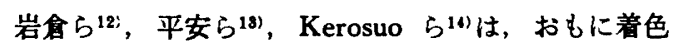
苗と鳋感受性の関連性について論じているが, 着色齿

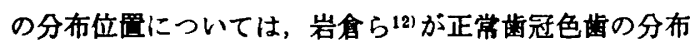
から離れた位置に分布する傾向を認めたと指摘している のみである。従って，これまでは，正常齿冠色歯の分 布, 着色齿, 白斑菌など色調の異常を呈した症例の分 布, さらに, 正常歯冠色齿との位置的関係については十 分に明らかにされていなかった現状にある。

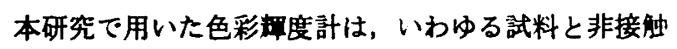
で測定可能な望遠式のものである。従来, 歯冠色調の研 究においては，接䖵式の測色器機を使用した報告が大部 分であり望遠式の器機を使用した報告例は少ない。理由 のひとつには, 接触式の場合, 望遠式のものと比較して 外部照明の影䇾を受けにくい長所が指摘される。しかし ながら, 测定面㮴は限定される（主に $\phi 2 \sim 3 \mathrm{~mm}$ ) 短 所がある。望遠式は, 测定面樌の設定は自由であり, 著 者らのごとく, 画面全体を評価しようとする際には, 有 用性が高いと考えられる。

本研究で用いた標準白色面からの色差の指標は, 色調 を複数の指標を総合化して, 単一の数值で評価すること が可能であった。従って, ヒトの歯冠色調の分布を評価 するうえで，色差は简便かつ有益な指標であることが実 証された。

以上, 本研究は蒛種別, 左右差, さらには部位別など 個々の色調の特徴について調查したものではないが，色 調の異常が局所に限局している症例では対象齿の部位別 の検討が今後必要と考えられた。

いわゆる白斑や着色淗の分布については症例が少なか ったこともあり，その分布型を特定することは出来なか ったことから，さらに検郡する必要性が認められた。

本研究から明らかなように，白斑菌や着色歯などの色 差は正常な歯冠色調の分布とは異なる位圈に分布する。 このことから, 色調の異常は, 色差を指標とした本測シ ステムにより識別することが可能であると思われた。

\section{結論}

集団における䖪冠色調の分布を，色彩輝度計を用いて 測定し, 標準白色面からの色差を指標として年龄群別, 症例別に検討した結果，以下の結論を得た。

1. 歯冠色調の色差の分布は, 全対象歯, 正常歯冠色 歯群では，小児，成人，ならびに全年龄群ともに正規分 布を示した。

2. 症例別では, 明らかな着色菌や白斑歯は小児, 成 人ならびに全年龄群ともに正常歯冠色路の平均值から約 2S.D. 離れた位固に分布していた。全年龄群と小児で は, 正常菊冠色歯群, 白斑菌群, 着色齿群の三群の色差 の平均値はいずれの組み合わせでも統計学的に有意の差 が絜められた $(\mathrm{P}<0.05)$ 。成人においては, 着色歯群と 正常齿冠色莯群, ならびに着色歯群と白斑歯群の間で統 計学的に有意の差が認められた $(\mathrm{P}<0.05)$ 。

3. 本測色システムにより歯冠色調の異常は, スクリ ーニングレベルを白斑崡では色差30.0末満, 着色崡では 40.0以上に設定することにより識別しうる可能性の高い ことが示唂された。

本研究の一部は, 昭和59年度文部省科学研究费補助金 (奖励研究 A 59771602) および財団法人「富徳会」研 究助成金によって行なわれた。

\section{辣 辞}

稿を終わるに当たり，本研究に御協力頂きました学校 関係者の皆样に感即の意を表します。さらに，本研究の 遂行に当たり御高配頂きました浜田明大先生, 松島静吾 先生，久米田俊英先生に心から感即申し上げます。

\section{文献}

1）宮越 等，小杉興三雄，景山六郎，河辺重勝， 奥津一更：日本人齿牙色調に関与る研究，第 1 報, 自記分光光度計による Detachable Tooth Shade Guide（米国 S.S.W. 会社㱔）の色調分

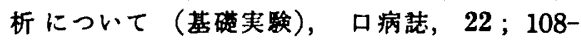
$119,1955$.

2）丸井昌夫：齔冠色関する研究，第 2 報 掬冠 色と皮店色の関連性, 口病就， $35 ; 422-440$, 1968.

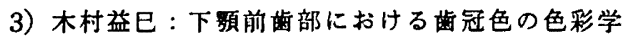
的研究, 補緅誌, $28 ; 1172-1186,1984$.

4) 山崎位夫：上頻前歯の色彩学的研究, 日歯保 誌, $29 ; 81-94,1986$.

5）中川亭暗：齿冠色分析に関する研究，補緅莎， $19 ; 109-130,1975$.

6）上原秀橵：上下影前齿の色彩学的研究，九州菌 
会誌, $34 ; 465-488,1981$.

7）槚口綽徳, 神津 䒨, 山本真也, 坂口㹂司, 伊 比第：口腔内の色彩に関する研究，第 5 報 Dental Color Analyzer による蔽牙の色彩と肉 眼的測定值について，松本齿学， $7 ; 205-220$, 1981.

8）一和多寿橵：齿に関する色彩学的研究一分光放 射测定法による検时一，補緅誌，30；652-664， 1986.

9）岡田透：児童の永久画の買常著色についての 疫学的研究, 日本公䘘誌, $28 ; 289-299,1981$.

10) Ulvestud, H., Lökken, P. and Mjörud, F. : Discoloration of permanent front teeth in 3157 nolwegian children due to tetracyclines and other factors, Scand. J. Dent. Res., 86 ; 147-152, 1978.

11）小川恭央：乳前曾の色調に関する研究，とくに 着色乳跑と健常乳苗との比較について, 日大口 窒科学, $8 ; 86-98,1982$.

12）岩合政城, 岛田義弘, 橴谷芳郎: 齿の色とう蚛 感受性との閶保についての研究, 東北大学齿学 研究, $6 ; 19-27,1979$.

13）平安造，姬野孝枝，河野敬一，寺田善博，坂 并共子，高橋省治：画牙色沢と耐亏䖵性との 関釈についての研究，補緅誌，28；316-321, 1984.

14) Kerosuo, E. and Kolehmainen, L.: The relationship between past caries experience and tooth color determind by an opto-electoronic method, Acta Odontol. Scand., 40 ; 451-457, 1982.

15）白土勝芳，岛田義弘：テトラサイクリン系抗生 物兵由来と思われる着色齿の研究，第 1 報 和 白齔における盖色齿，黄色線条ならびに螢光線 条の出現状況とそれらの関連性について，口腔 街生会誌, $34 ; 72-80 ， 1984$.

16）宮澤正人，饭岛洋一，長田齐，稲菜大烳，田 沢光正，片山 䣓: 色彩計による蓬冠色调の砰 価，口腔笛生会誌，34；234-235，1984.

17）宮笝正人, 長田 斉, 稲菜大輔, 田沢光正, 饭 岛洋一，片山刚: 青森県下北郡東通村に認め

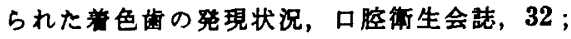
217, 1982.

18）池田光男: 色彩工学の基礦, 朝會書店, 東京, 1980, 61-149頁.

19）JIS Z 8722 （1982）物体色の测定方法, 日本規 格劦会, 東京.

20) Winer, B. J. : Statistical principles in experimental design, McGraw-Hill, New York, 1971, 2nd edtion, p. 201.

21）重松逸造編著：度学一臨床家のための方法諭， 講锁社, 東京, 1978, 31-39頁.

22）檑口綽德：齿科医学における色彩の科学, 松本 齿学, 8 ; 171-196, 1982. 